\title{
Pygospio elegans (Annelida: Spionidae) - an annelid model for regeneration studies
}

\author{
V.V. Starunov', G.A. Barmasova², M.A. Nesterenko², \\ M.A. Kulakova², E.L. Novikova² \\ ${ }^{1}$ Zoological Institute RAS, Universitetskaya nab. 1, St-Petersburg 199034, Russia. \\ ${ }^{2}$ St.-Petersburg State University, Universitetskaya nab. 7-9, St-Petersburg, 199034 Russia. \\ E-mail: elena.novikova.03.06@gmail.com
}

\begin{abstract}
Pygospio elegans Claparède, 1863 is a sedentary tube-dwelling annelid belonging to Spionidae family. Its prominent regeneration abilities, as well as its small size, widespread distribution and environmental tolerance make $P$. elegans a perfect annelid model for studying cellular and molecular mechanisms of regeneration, larval and postlarval growth. Here we performed staging of $P$. elegans regeneration, which will be useful for future molecular studies of the reparation process. We also described some morphological aspects of anterior and posterior post-traumatic regeneration of $P$. elegans collected on the Barents Sea, including muscle and catecholaminergic nervous system regeneration.

How to cite this article: Starunov V.V., Barmasova G.A., Nesterenko M.A., Kulakova M.A., Novikova E.L. 2020. Pygospio elegans (Annelida: Spionidae) — an annelid model for regeneration studies // Invert. Zool. Vol.17. No.3. P.247-266. doi: 10.15298/invertzool. 17.3.04
\end{abstract}

KEY WORDS: Pygospio elegans, regeneration, scanning electron microscopy, annelids, molecular control, evolution.

\section{Pygospio elegans (Annelida: Spionidae) - модель для изучения регенерации}

\section{В.В. Старунов ${ }^{1}$, Г.А. Бармасова², М.А. Нестеренкоㄹ, М.А. Кулакова², Е.Л. Новикова²}

\footnotetext{
${ }^{1}$ Зоологический институт РАН, Университетская наб. 1, Санкт-Петербург, 199034 Россия. ${ }^{2}$ Санкт-Петербургский государственный университет, Университетская наб. 7-9, СанктПетербург, 199034 Россия.

E-mail: elena.novikova.03.06@gmail.com
}

РЕЗЮМЕ: Pygospio elegans Claparède, 1863 - сидячая аннелида из семейства Spionidae. Прекрасные регенерационные возможности этого червя в сочетании с небольшими размерами, широким распространением и способностью адаптироваться к разным условиям окружающей среды делают $P$. elegans удачным модельным объектом для изучения процессов регенерации, личиночного и постларвального роста на клеточном и молекулярном уровнях. В данной работе мы провели стадирование основных этапов регенерации P. elegans, что представляется важным для дальнейшего изучения процессов репарации на молекулярном уровне. В работе 
также приведено описание морфологических аспектов передней и задней регенерации мускулатуры и катехоламинергической нервной системы.

Как цитировать эту статью: Starunov V.V., Barmasova G.A., Nesterenko M.A., Kulakova M.A., Novikova E.L. 2020. Pygospio elegans (Annelida: Spionidae) — an annelid model for regeneration studies // Invert. Zool. Vol.17. No.3. P.247-266. doi: 10.15298/invertzool. 17.3.04

КЛЮЧЕВЫЕ СЛОВА: Pygospio elegans, регенерация, сканирующая электронная микроскопия, аннелиды, молекулярный контроль, эволюция.

\section{Introduction}

Annelids are among the most important groups to study regeneration processes in animals (Bely, 2006; Ferrier, 2012; Kostyuchenko et al., 2016). Being highly organized creatures, they can perfectly regenerate both anterior and posterior parts of the body. Nevertheless, regenerating abilities vary a lot not only among different annelid families, but also among species belonging to the same genus (Hyman, 1940; Berrill, 1952; Bely et al., 2014). For example, the sabellid Myxicola infundibulum Montagu, 1808 cannot survive after its head structures were amputated while Myxicola aesthetica Claparède, 1870 can regenerate both body ends from the single segment (Wells, 1952). Thus, this stunning variation of regeneration capacities gives rise to a huge question why some annelids can regenerate both head and "tail" parts, sometimes from one segment, while others can hardly heal the wound.

Annelids which are comprised of Errantia, Sedentaria and a few basally branching clades (Struck et al., 2011, Weigert et al., 2014) are now becoming more and more popular models for studying variable developmental processes and regeneration. Among annelid species that are currently under intense investigation are Platynereis dumerilii Audouin et Milne Edwards, 1833 (Nereididae) (Fischer et al., 2010; Planques et al., 2019), Alitta virens M. Sars, 1835 (Nereididae) (Bakalenko et al., 2013; Novikova et al., 2013; Kozin et al., 2017), Capitella teleta Blake, Grassle et Eckelbarger, 2009 (Capitellidae) (de Jong, Seaver, 2016; de Jong, Seaver, 2017) and Pomatoceros lamarckii Quatrefages, 1866 (Serpulidae) (Szabó,
Ferrier, 2014). All except the last one have been shown to be good posterior regenerating models (de Jong, Seaver, 2016; Kozin et al., 2017; Planques et al., 2019), but none of them is capable of regenerating the head part. Besides, the most studied P. dumerilii and Alitta virens are from Errantia group and, with some assumptions, can be regarded as characteristic for that clade. At the same time $C$. teleta and P. lamarckii represent highly derived conditions of sedentary annelids. Thus, the acute need in a new model that would be able to regenerate both, anterior and posterior parts of the body arises. Here we propose a new model species Pygospio elegans Claparède, 1863 that belongs to Spionidae (Sedentaria). This annelid is capable of both anterior and posterior regeneration and also demonstrates many features that can be regarded as ancestral for Sedentaria such as small parapodia lacking internalized supporting chaetae, the absence of antennae, sedentary lifestyle, microphagy, and grooved (ciliated) palps (Struck et al., 2011; Weigert et al., 2014).

In the introduction to this paper we summarize the information about Pygospio elegans from different sources including thesis and old books. This review of $P$. elegans lifestyle, environmental preferences, reproduction modes and different aspects of development could be of some value and serve to encourage developmental and molecular biologists to include $P$. elegans into their research. In the Results of the paper we present our own data on the external morphology of Pygospio elegans collected on Barents Sea at Dalnie Zelentsi, the dynamics of its anterior and posterior regeneration after traumatic amputation under laboratory conditions 
at $18^{\circ} \mathrm{C}$, including muscle and catecholaminergic nervous system regeneration. Based on our results we perform the staging of $P$. elegans regeneration that will be very useful in the future studies of genetic and molecular regulation of the reparation process.

P. elegans is a small sized $(10-15 \mathrm{~mm})$, tube-dwelling annelid that inhabits Arctic, as well as Northern regions of Atlantic and Pacific Oceans (GBIF Secretariat, 2019). Members of the species can form high density patches, or tube-beds, with densities up to 600000 individuals per $\mathrm{m}^{2}$ (Morgan, 1997) and prefer intertidal mud and sand flats (Thonig et al., 2016). P. elegans exhibits wide habitat tolerances and can be found on lower supralittoral as well as on 100 $\mathrm{m}$ depth with the salinity ranging from $2 \%$ to hypersaline pools (Morgan, 1999; Thonig, 2018). It also displays a variety of feeding strategies and can act as a deposit-, suspensionand probably filter-feeder (Hempel, 1957). $P$. elegans displays opportunistic life strategy and takes advantage of the "pioneer" niche rapidly re-colonising defaunated substrates (McCall, 1977; Morgan, 1999).

\section{Sexual reproduction and larval develop- ment}

Pygospio elegans is dioecious and sexually dimorphic. Males are described to have an additional pair of branchiae on the second chaetiger and well-developed sense organs (Söderström, 1920; Fauchald, Jumars, 1979; Schlotzer-Schrehardt, 1991). Nototrochs that start from the chaetiger 2 comprise transverse single rows of ciliated cells extending onto branchia in females and double rows with anterior row extending onto branchia in males (Radashevsky et al., 2016). Rasmussen observed in the population at Horsens Fjord that the ratio of males and females varied from month to month. Later in the laboratory experiments, he showed that sex reversal took place depending on the water temperature. When the temperature increased from 5 to $18{ }^{\circ} \mathrm{C}$ ripe males turned into unripe females by not only reversing the secondary sexual characters but also by degeneration of the ripe sperm (Rasmussen, 1973). On the contrary, Rada- shevsky et al. (2016) describe P. elegans as gonochoristic.

Spawning period may occur at any time of the year depending on the location of the population. Rasmussen observed sexual reproduction in September-October which decreased through the cold season and completely stopped in March at Horsens Fjord (Denmark). At Isefjord it took place in late winter - May (Denmark) (Rasmussen, 1973). Malikova recorded the presence of Pygospio larvae in plankton in July-August on the White Sea and Barents Sea (Russia) (Malikova, 1975; Malikova, Plyusch, 1980; Malikova, Sokolova, 1992a, b) and Hannerz collected larvae at Gullmar fjord (Sweden) in February (Hannerz, 1956).

Morgan et al. (1999) observed that fertilization was preceded by copulation which is quite unusual for a tube dwelling spionid (Morgan et al., 1999). Söderström (1920) describes the presence of spermatophore and Hannerz (1956) suggests that spermatophore of the male is transferred to the spermatotheca of the female (after Lapp Armitage, 1979). Spermatophores are formed in the epitokous nephridia and contain intrasperms with long head and demarcated acrosome (Hannerz, 1956).

Females produce eggs of two types. Rasmussen describes the eggs of the first type as clear, poor in yolk with a distinct nucleus and about $100 \mu \mathrm{m}$ in diameter which are called true or genuine eggs. The second type are nurse eggs that contain dense orange-colored yolk, lack a distinct nucleus, and measure from 6 to $70 \mu \mathrm{m}$ in diameter. Eggs are laid into external capsules extruded by the parent. Each of the thin-walled capsules contain the products of one gametogenous chaetiger (Rasmussen, 1973). Up to 34 capsules are joined in a string and each attached by one stalk to inside wall of tube (Radashevsky et al., 2016). The number of eggs/embryos in one capsule was reported different by different authors: Rasmussen (1973): 125-250, Soderstrom (1920): 50-60, and Smidt (1951: 55): max. 25 per capsule.

$P$. elegans displays variation in developmental mode, also called poecilogony. The larval types produced by the worm may be strictly 
defined for a certain population (Morgan et al., 1999; Anger, 1984) or depend on the season of spawning (Hannerz, 1956; Rasmussen, 1973). Sometimes the population can produce larvae of different types at the same time (Rasmussen 1973; Gudmundsson 1985; Kesäniemi et al., 2012). The ratio of true eggs to nurse eggs indicates the mode of development.

Planktonic larvae emerge from egg capsules containing more than 20 genuine eggs (Kesäniemi et al., 2012). These larvae develop three chaetigers inside the capsule before hatching (Radashevsky et al., 2016). They possess swimming chaetae and feed and develop in plankton for about 4-5 weeks (Anger et al., 1986). After reaching the stage of 12-19 chaetigers larvae start to seek a suitable substrate and eventually settle to commence the benthic life (Thonig et al., 2016).

If only a few true eggs are laid they keep developing inside the capsule till 14-19 chaetiger stage, feeding on nutritions provided by the nurse eggs (Radashevsky et al., 2016). The round shaped embryo develops into a 3-segment lecitotrophic larva full of yolk, localized on the dorsal side of the animal (Rasmussen, 1973; Malikova, Sokolova, 1992b). The larvae of this type keep developing inside the capsule and settle immediately after hatching at 14-20 chaetiger stage.

The intermediate larval type was also recorded. These larvae develop 6-10 chaetigers inside the capsule, reach 14-19 segments in the plankton after hatching and then settle (Kesäniemi et al., 2012; Radashevsky et al., 2016). Larvae possess nototrochs from chaetiger 3 onwards, neurotrochs terminated by ciliated pit on chaetiger 2 and gastrotrochs on chaetigers 3 , 5, 7, and 11 (Radashevsky et al., 2016).

\section{Asexual reproduction}

Pygospio elegans reproduces both sexually and asexually by architomy in most studied populations (Rasmussen, 1953). Rasmussen describes asexual reproduction of $P$. elegans at Horsensfjord (Denmark) in spring. The adult male and female bodies are divided into several fragments consisting of varying number of seg- ments, usually three or four. Sometimes fragments of only one segment size were observed that infers high regenerative potential of this worm. In general, the splash of asexual reproduction was reported following the lowest seasonal temperatures probably in order to restore rapidly the population density (Rasmussen, 1973; Armitage, 1979).

\section{Experience of the cultivation in the labo- ratory conditions}

The most successful cultivation methods of Spionids including Pygospio elegans were described in Anger et al, 1986. P. elegans were collected in the North Sea, kept in the filtered sea water at $12{ }^{\circ} \mathrm{C}$ with salinity around $32 \%$ and fed with the mixture of flagellates (Dunaliella tertiolecta) and diatoms (Thalassiosira rotula). For $P$. elegans 16 successive generations were cultivated with the average life span comprising 9 months. After metamorphosis and settlement, the first reproduction (hatching of larva) occurred in around 3 months (min 87 days) at $12{ }^{\circ} \mathrm{C}$ and in 81 days at $18{ }^{\circ} \mathrm{C}$. Pelagic larval development lasted 4-5 weeks and minimum benthic existence occupied 15-17 weeks. The individuals of this population produced feeding larvae that hatched at three-segment stage with the body length of 250-330 $\mu \mathrm{m}$ and reached 15chaetiger stage in $26-43$ days at $12{ }^{\circ} \mathrm{C}$ and in 20-40 days at $18{ }^{\circ} \mathrm{C}$. 15 -chaetiger larvae were considered metamorphic as the first examination of substrate and first tube building occurred at 14-chaetiger stage, though swimming often continued until $18^{\text {th }}$ chaetiger appeared.

\section{Materials and methods}

Animals were collected at the intertidal zone near the marine biological station Dalnie Zelentsi (Barents Sea, 69 $07^{\prime} \mathrm{N}, 36^{\circ} 05^{\prime} \mathrm{E}$ ). The animals were kept at $18^{\circ} \mathrm{C}$ in plastic bowls filled with sand and artificial sea water (Red Sea Coral Pro Salt) with salinity about 32\%o. For regeneration experiments animals were cut with a razor blade after $8^{\text {th }}-10^{\text {th }}$ or $20^{\text {th }}$ body segment and incubated in separate Petri dishes at $18{ }^{\circ} \mathrm{C}$. 
The following time points for regeneration experiment fixations were chosen: 0 hpa (hours post amputation), $4 \mathrm{hpa}, 12 \mathrm{hpa}, 24 \mathrm{hpa}, 48 \mathrm{hpa}$, 3 dpa (days post amputation), 4 dpa and 7 dpa. For animals dissected after $8^{\text {th }}$ or $10^{\text {th }}$ segment the observations were prolonged up to 1.5 months.

For scanning electron microscopy, the animals were relaxed in $7.5 \% \mathrm{MgCl}_{2}$ and fixed in $2.5 \%$ glutaraldehyde in $0.1 \mathrm{M}$ phosphate buffer (PB, pH 7.2). The osmotic pressure was adjusted with $\mathrm{NaCl}$. After fixation, the specimens were rinsed 1-3 times in $\mathrm{PB}$ with $0.3 \mathrm{M} \mathrm{NaCl}$ and post- fixed in $1 \% \mathrm{OsO}_{4}$ in the same buffer. The specimens were dehydrated in acetone series of increasing concentration, critical point dried, coated with platinum, and examined under FEI Quanta 250 scanning electron microscope (FEI Company, The Netherlands) or Tescan Mira3 LMU (Brno, Czech Republic).

For muscle staining the worms were relaxed in $7.5 \% \mathrm{MgCl} 2$ and fixed in $4 \%$ Paraformaldehyde at $0.1 \mathrm{M}$ phosphate buffered saline (PBS, $\mathrm{pH}=7.4$ ) for $8-12 \mathrm{~h}$ at $+4{ }^{\circ} \mathrm{C}$ or $3-6 \mathrm{~h}$ at room temperature. After fixation the specimens were washed 3 times for $30 \mathrm{~min}$ in PBS, containing $0.1 \%$ Triton $\mathrm{X}-100$ (PBT) and stored in PBS with $0.1-0.05 \% \mathrm{NaN} 3$ at $+4{ }^{\circ} \mathrm{C}$. The worms were stained with $1 \mu \mathrm{g} / \mathrm{ml}$ TRITC-conjugated phalloidin(Sigma, P1951) in PBT for 2 h, mounted in Mowiol and examined using Leica TCS SPE or Leica TCS SP5 laser confocal microscopes (Leica Microsystems, Wetzlar, Germany).

For nervous system staining a glyoxylic acid fluorescent technique was employed to visualize catecholamine-containing cells. Worms were immersed in a freshly prepared, buffered glyoxylic acid-sucrose solution $(500 \mathrm{mM}$ sodium glyoxylate, $150 \mathrm{mM}$ sucrose, $50 \mathrm{mM}$ Tris buffer, $\mathrm{pH}$ 7.4) on glass slides at $4{ }^{\circ} \mathrm{C}$. After 60 minutes of incubation, the solution was removed, and the worms were air-dried at room temperature for 30 minutes. Preparations were then heated to $60{ }^{\circ} \mathrm{C}$ for 30 minutes, embedded in paraffin oil, and examined using Leica TCS SP5 laser scanning microscope (excitation at 405 $\mathrm{nm}$, emission detection at $457-490 \mathrm{~nm}$ ).

\section{Results}

\section{Adult morphology}

P. elegans body can reach $70-80$ segments length and consists of head (prostomium and peristomium), trunk segments which can be subdivided into three regions - thorax, abdomen and "tail", and pygidium (Fig. 1A). Prostomium with anterior incision is bearing two pairs of eyes and a medial nuchal crest, called caruncle that reaches the chaetiger 2. On both sides of caruncle nuchal organs' ciliary bands are placed. The long and curly palps grow out of the posterior part of the prostomium (Fig. 1B-C). Palps bear longitudinal ciliated feeding grooves to transport food to the mouth (Fig. 1B). Based on the presence of branchiae on abdominal segments and specific mode of regeneration of the segments of different body parts we divide the Pygospio trunk into thorax, abdomen and tail regions. The thoracic region of $P$. elegans in the studied population mostly consists of 12 chaetae-bearing segments (chaetigers) (Fig. 1D), though the number of thoracic segments may vary from 10 to 13 chaetigers (Gibson, Harvey, 2000; Radashevsky et al., 2016). We examined more than 500 worms from the studied population and only a few contained 13 thoracic segments. Thus, for the regeneration experiments we only picked animals with 12 thoracic chaetigers.

Chaetigers bear biramous parapodia with capillary notochaetae on all segments and capillary neurochaetae on the first 7 segments (Fig. 1E). From segment 8 to 12 neurochaetae are spoon-like hooks (Fig. 1E, G). Abdominal region which starts from the $13^{\text {th }}$ segment contains branchiate chaetigers with branchia fused to notopodial postchaetal lamellae and ciliation along inner surface (Fig. 1F). Neuropodia carry hooded hooks from the $13^{\text {th }}$ segment throughout the body (Fig. 1F, H).

The "tail" contains 6 to 12 abranchiate chaetigers with capillary notochaetae, neurochaetae that are hooded hooks (Fig. 1I-K). The pygidium bears one pair of dorsal cirri and one pair of slightly thicker and longer ventral cirri, each with tufts of cilia on the inner surface (Fig. $1 \mathrm{~K}-\mathrm{L})$. 

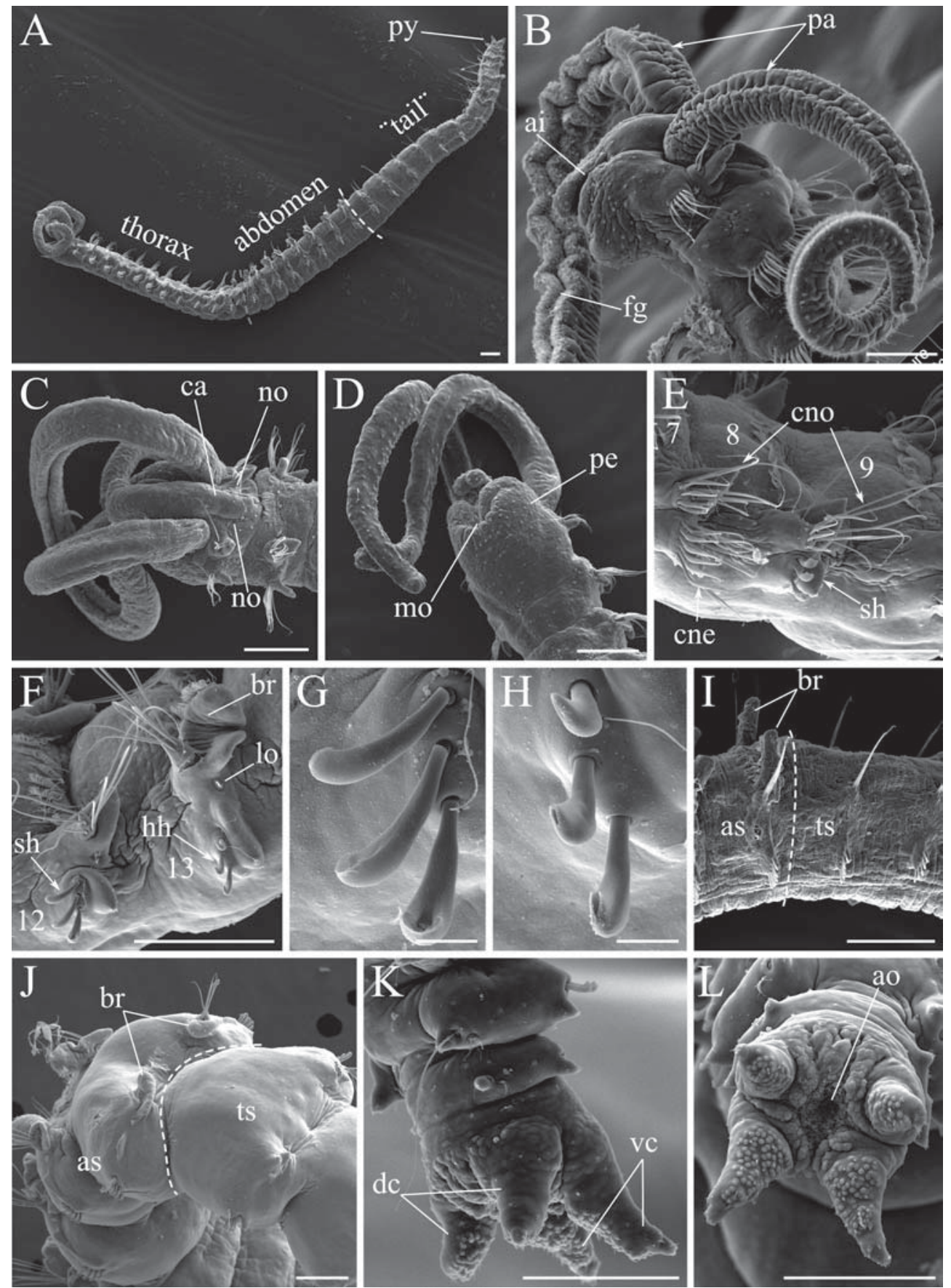

Fig. 1. Pygospio elegans, adult worm morphology. A — general view of a young worm. Line demarcates the border between the thoracic and abdominal regions, white dotted line marks the border between abdominal and "tail" regions. B, C, D - head of the worm with curly palps and first body segments, lateral view (B), dorsal view (C), ventral view (D). E - the part of the thoracic region with 8th and 9th segments, lateral view. $\mathrm{F}$ - the part of the body covering the last thoracic and the first abdominal segments with the branchia, lateral view. G - spoon-like hooks. H - hooded hooks. I-J - the part of the body covering the 


\section{Anterior and posterior regeneration}

Regeneration process was studied at $18^{\circ} \mathrm{C}$. In the first series of the experiments we cut the worms into two halves between $20^{\text {th }}$ and $21^{\text {st }}$ body segments (the $8^{\text {th }}$ and $9^{\text {th }}$ abdominal segments). We refer to the cut site where the head grows as the head site and the cut site where the "tail" grows as the "tail" site.

In the first 4 hours after the amputation the muscle constriction occurs on both regenerating sites to prevent the leakage of the body fluid (Fig. $2 \mathrm{~A}-\mathrm{C})$. After the muscle constriction the intestine can be located inside the body cavity (Fig. 2B) or everted (Fig. 2C), which, in fact, does not influence the rate and course of regeneration.

In 12 hours, the regenerative epithelium starts to cover the wound surface (Fig. 2D-F), and by the end of Day 1 the smooth surface is formed and the blastema formation is hardly distinguishable (Fig. 2G-I). By Day 2 the blastema is prominent on both head and "tail" regenerative sites (Fig. 2J-K).

On Day 3 the elongation of head bud and mouth opening invagination is observed (Fig. 2L). The "tail" regenerating part possesses clearly visible double lobed structure (Fig. 2M).

By Day 4 organogenesis proceeds at full speed. On the head site the head and thorax are regenerating. The head bears palp buds. The mouth invagination is forming. The segmentation signs are evident on the thoracic anlage and 9-10 segments can be distinguished (Fig. $2 \mathrm{~N}-\mathrm{O})$.

The "tail" site displays the restored pygidium with small cirri that are still forming. The segmentation on the "tail" site is in progress but only a few segments are visible due to the slight wrinkles that reveal the early segmentation process (Fig. 2P).

By Day 7 the anterior regenerating part consists of head with growing palps, nuchal organ rudiments and mouth invagination and the thoracic region with the anlagen of twelve segments (Fig. 2Q-R). Growing "tail" part keeps producing new segments and the pygidium is clearly distinguishable and almost formed (Fig. 2S).

In the second series of the experiments we cut the worms between the $8^{\text {th }}$ and $9^{\text {th }}$ or $10^{\text {th }}$ and $11^{\text {th }}$ body segments which are the part of the thoracic region. The general course of regeneration in this case is very similar to the previously described though the regeneration rate is a bit lower in case of posterior regeneration.

Anterior regeneration proceeds almost at the same speed as in previously described ex-

last abdominal segment with branchiae and the first segment of the "tail" region, lateral view (I), dorso-lateral view $(\mathrm{J})$. The white dashed line marks the border between two body regions. $\mathrm{K}-\mathrm{L}-$ pygidium with cirri, lateral view (K), back view (L).

Abbreviations: ai — anterior incision; ao — anal opening; as — abdominal segments; br — branchia; ca — caruncle; cne - capillary neurochaetae; cno - capillary notochaetae; dc — dorsal cirri; fg — feeding groove; hh — hooded hook; lo - lateral organ; mo - mouth opening; no — nuchal organ; pe — peristomium; sh — spoon-like hook; ts — "tail" segments; vc - ventral cirri. Orientation of the figures - anterior to the left, dorsal side to the top. Scale bar: A-F and $\mathrm{I}-\mathrm{L}-100 \mu \mathrm{m} ; \mathrm{G}, \mathrm{H}-20 \mu \mathrm{m}$.

Рис. 1. Pygospio elegans; внешняя морфология взрослого червя. А - общий вид растущего червя. Пунктирная линия маркирует границу между грудным и абдоминальным отделами тела; белая пунктирная линия соответствует границе между абдоминальным и хвостовым отделами. B-D головной отдел червя с закрученными пальпами и несколькими сегментами тела; В - вид сбоку; $\mathrm{C}$ вид со спины; D - вид с брюшной стороны. Е - часть грудного отдела, включающая 8-й и 9-й сегменты, вид сбоку. F — часть тела, включающая последний грудной сегмент и первый абдоминальный сегмент с жаброй, вид сбоку. G - ложковидные щетинки; H - крючковидные щетинки. I-J - часть тела, включающая последний абдоминальный сегмент с жаброй и первый сегмент хвостового отдела; I - вид сбоку; J - дорсо-латеральный вид. Белым пунктиром обозначена граница между двумя отделами тела. $\mathrm{K}-\mathrm{L}$ — пигидий с циррами; $\mathrm{K}$ - вид сбоку; L — вид сзади.

Обозначения: ai — передняя ямка; aо — анальное отверстие; as — абдоминальные сегменты; br — жабра; са — карункул; cne — капиллярные неврохеты; cno — капиллярные нотохеты; dс — дорсальные цирры; fg — ресничная бороздка; hh — крючковидная щетинка; lo — латеральный орган; то — ротовое отверстие; по — нухальный орган; pe — перистомиум; sh — ложковидная щетинка; ts — сегменты хвостового отдела; vс — вентральные цирры. Ориентация: передний конец тела слева, дорсальная сторона сверху. Масштаб: A-F и I-L $100 \mu \mathrm{m} ; \mathrm{G}, \mathrm{H}-20 \mu \mathrm{m}$. 

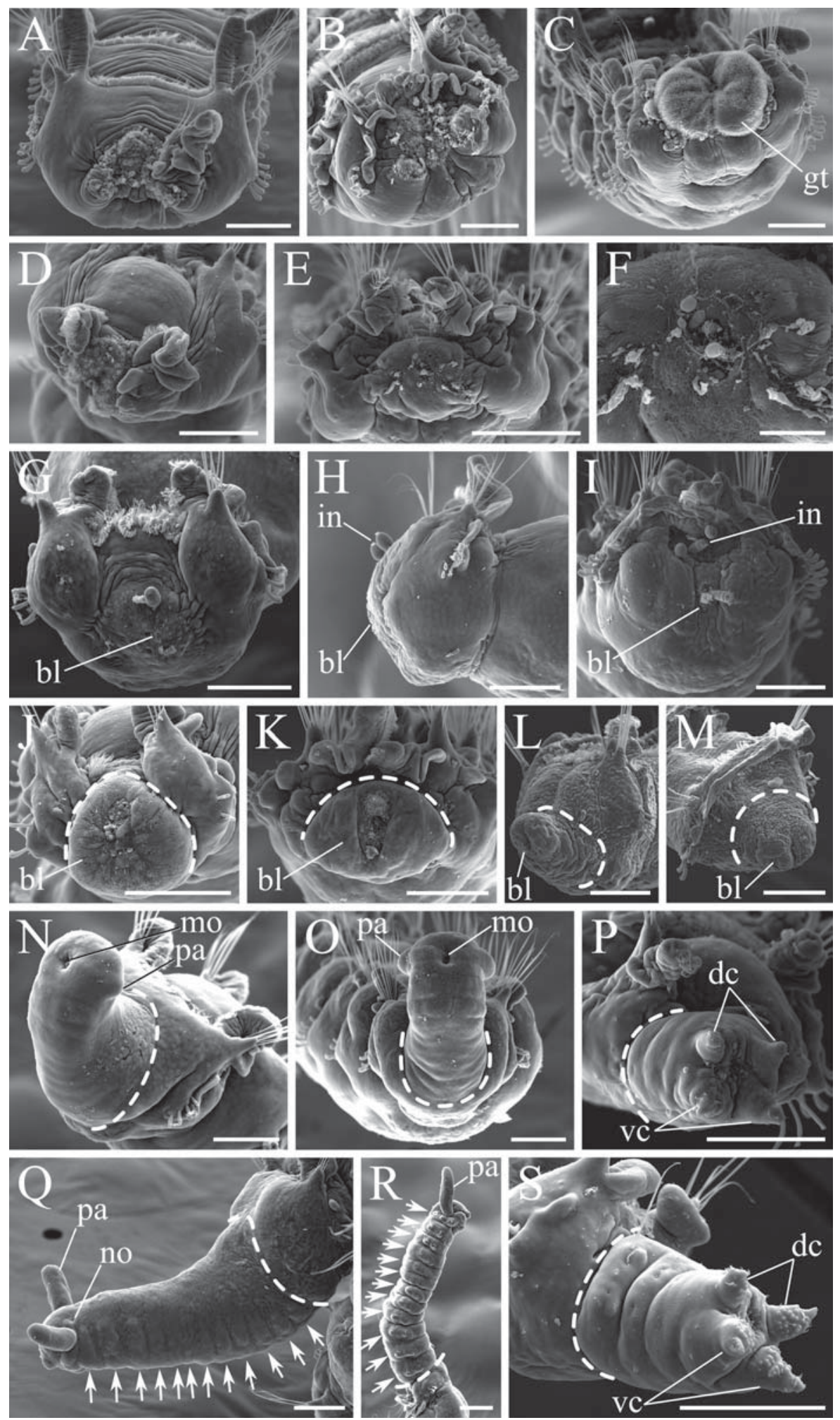
periments. By Day 4 the forming head with the palp buds is visible (Fig. 3A) and by Day 7 the thorax with 8 or 10 (depending on the amputation level) newly forming segments with parapodial anlagen is clearly distinguishable (Fig. 3C). By Day 14 of regeneration the capillary chaetae on notopodia and neuropodia grow out on the first 7 segments and the $8^{\text {th }}$ newly formed segment bears spoon-like neurochaetae (Fig. 3E-F).

We observed posterior regeneration for 10 segment pieces, since worms cut after $8^{\text {th }}$ thoracic segment survived poorly. In 4 days, the regenerating "tail" part consists of the forming pygidium with hardly distinguishable cirri buds (Fig. 3B). By Day 7 the cirri and a few segments are visible (Fig. 3D), and by Day 14 the worm keeps adding new segments (Fig. 3G). The newly formed segments bear the identity of "tail" segments (abranchiate segments with hooded hooks). In 3 weeks two first regenerated segments which are adjacent to the old thoracic segments have no branchiae, but preserve hood- ed hooks in their neuropodia (Fig. 3H-I). The next segments eventually grow branchiae (Fig. $3 J)$. The 4-5 week regenerates keep adding "tail" segments, and more and more "tail" segments achieve abdominal morphology (Fig. 3J, L). The regenerated thoracic segments preserve hooded hooks in neuropodia (Fig. 3K, M).

\section{Muscular system regeneration}

For correct staging of restoration process, we also performed TRITC-phalloidin staining of regenerating musculature. During the first day of regeneration the muscle contraction occurs on both sites (Fig. 4A-B). Simultaneously, the destruction of the damaged muscle fibers begins that is still detectable on 2 dpa (Fig. $4 \mathrm{C}-$ D). On 4 dpa the almost formed pygidium musculature is detectable. It consists of circular muscle fibers surrounding the forming hindgut. The newly formed lateral longitudinal muscle bands are also clearly visible (Fig. 4F). Medial longitudinal muscles as well as transverse mus-

Fig. 2. Regeneration of Pygospio elegans after the dissection was performed between the $20^{\text {th }}$ and $21^{\text {st }}$ body segments. A-C - regeneration of head (A) and "tail" (B, C) 4 hpa (hours post amputation); transverse view. D-F - regeneration of head (D) and "tail" (E, F) 12 hpa; transverse view. G-I - regeneration of head (G, H) and "tail" (I) 24 hpa. The beginning of blastema formation can be distinguished. G, I - transverse view; $\mathrm{H}$ - lateral view. J-K - regeneration of head (J) and "tail" (K) $48 \mathrm{hpa}$. The fully formed blastema is clearly visible. Frontal view. L-M - 3 dpa (days post amputation); L — head formation; M - "tail" formation. $\mathrm{N}-\mathrm{P}-4 \mathrm{dpa}$. N, O - the formation of head with mouth opening and pulp buds and thoracic region from anterior blastema. P - "tail" part with pygidial cirri anlagen and signs of segmentation. Q-S - 7 dpa. Q, $\mathrm{R}$ - head and thorax regeneration. Palps are growing, the nuchal organs rudiments are visible and the anlagen of 12 thoracic segments are clearly distinguished (marked by arrows). S - "tail" part regeneration. Pygidial cirri are growing and posterior segmentation is visible.

Abbreviations: bl — blastema; dc — dorsal cirri; gt — gut; in — epibiotic ciliates (Peritricha); mo - mouth opening; pa - palps; vc - ventral cirri. White dashed line marks the cut line. Orientation of the figures - anterior to the left, dorsal side to the top. Scale bar: $100 \mu \mathrm{m}$ except for F $-20 \mu \mathrm{m}$.

Рис. 2. Регенерация Pygospio elegans после разреза между 20-м и 21-м сегментами тела. А-C регенерация головного (A) и хвостового (B, C) отделов 4 чпа (часа после ампутации), поперечный вид. D-F - регенерация головного (D) и хвостового (E, F) отделов 12 чпа, поперечный вид. G-I регенерация головного $(\mathrm{G}, \mathrm{H})$ и хвостового (I) отделов 24 чпа. Видно начало формирования бластемы. G, I - поперечный вид; Н - вид сбоку. J-K - регенерация головного (J) и хвостового (K) отделов 48 чпа. Хорошо видна полностью сформированная бластема. Поперечный вид. L, M - 3 дпа (дня после ампутации); L — формирование головного отдела; $\mathrm{M}$ - формирование хвостового отдела. $\mathrm{N}-\mathrm{P}-4$ дпа. $\mathrm{N}, \mathrm{O}-$ формирование головного отдела с ротовым отверстием и зачатками пальп, а также грудного отдела из передней бластемы. Р - хвостовой отдел с зачатками пигидиальных цирр и признаками сегментации. Q-S - 7 дпа. Q, R - регенерация головы и грудного отдела. Продолжается рост пальп, видны зачатки нухальных органов, четко различимы зачатки 12 грудных сегментов (отмечены стрелками). S - регенерация хвостового отдела. Продолжается рост пигидиальных цирр, видны признаки задней сегментации.

Обозначения: bl - бластема; dc - дорзальные цирры; gt — кишка; in - эпибиотические инфузории (Peritricha); mо - ротовое отверстие; ра — пальпы; vс — вентральные цирры. Линия разреза обозначена белым пунктиром. Ориентация: передний конец тела слева, дорсальная сторона кверху. Масштаб: $100 \mu \mathrm{m}$ кроме F - $20 \mu \mathrm{m}$. 

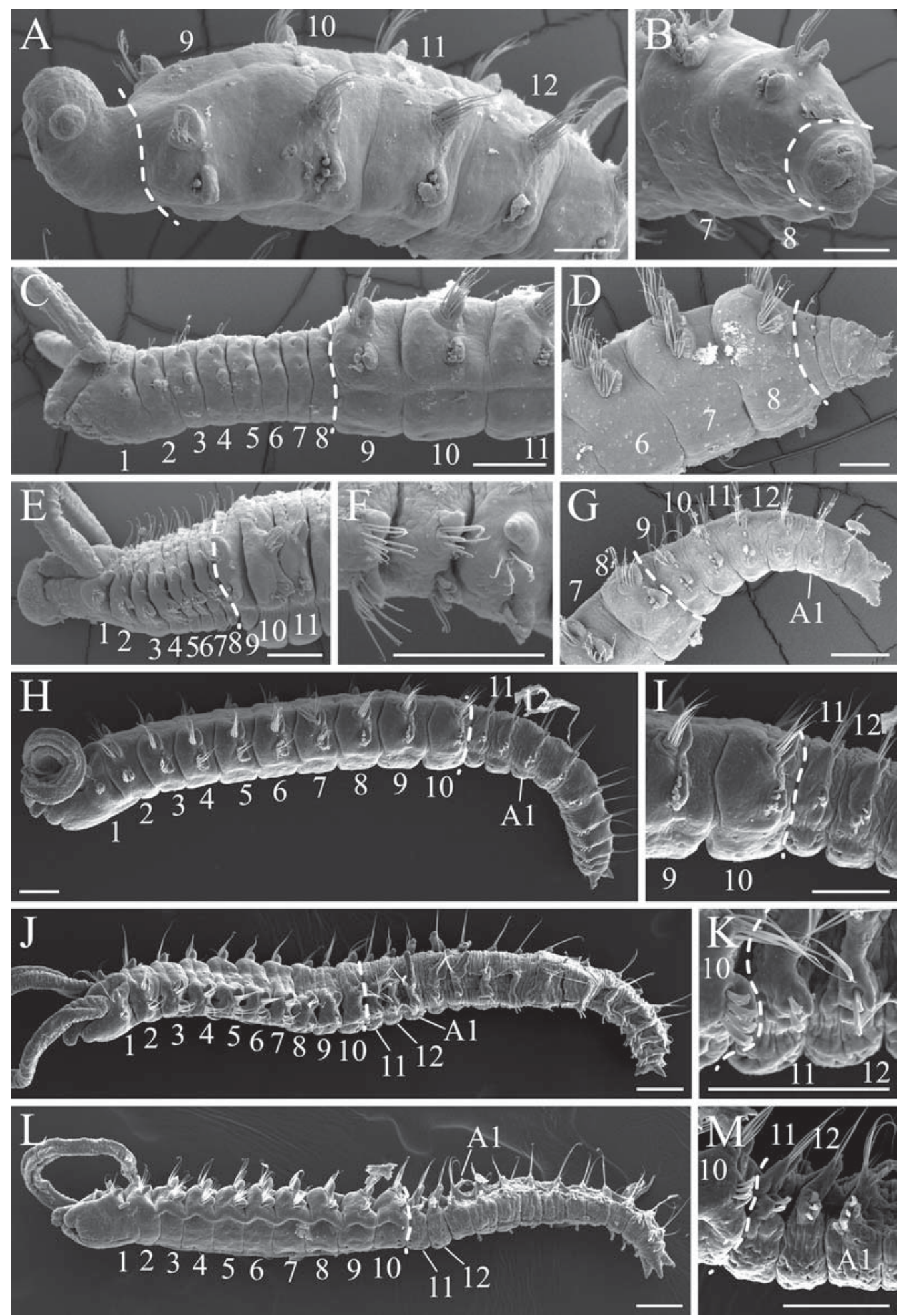
cles are not found at this stage. In the anterior regenerating part, the rudiments of longitudinal muscles as well as muscular elements around the forming mouth opening appear at 3-4 dpa (Fig. 4E). Thin transverse muscle fibers become visible on the ventral side at $4 \mathrm{dpa}$. At 7 dpa the musculature is fully formed. At the anterior site the longitudinal muscle bands, head, palp and parapodial musculature are observed. At the posterior site the segment muscles on various stages of development are visible (Fig. 4G-H).

\section{Catecholaminergic nervous system regen- eration}

Additionally, we studied the dynamics of catecholaminergic nervous system regeneration by glyoxylic acid fluorescent technique. It was determined that the first signs of nervous elements restoration reveal themselves only by $2-$ 3 dpa (Fig. 5A-B; Fig. 6A-B). At this stage the single sensory cells at the anterior and posterior sites become visible (Fig. 5B-C, 6B-C).

In the posterior regenerating part the number of marked cells drastically increases by 4 dpa (Fig. 6D). Their multiple projections are clearly traced in the forming ventral nerve cord which becomes more prominent by Day 7 (Fig. $6 \mathrm{E})$. Most of the stained cells are located in the pygidium (Fig. 6D-E).

In regenerating head only a few catecholamine positive cells are visible by $3 \mathrm{dpa}$ (Fig. 5CD), but their number slightly increases by $4 \mathrm{dpa}$ (Fig. 5E-F). It is worth mentioning, that the projections of the first stained cells in the forming head contribute to the dorsal longitudinal nerve, but not to the ventral nerve cord (Fig. $5 \mathrm{E})$. After the $4 \mathrm{dpa}$ the rapid formation of anterior catecholaminergic system occurs. By Day 7 we observe the strong fluorescence signal in the cerebral ganglion, especially in neuropil, in circumoesophagial connectives, ventral nerve cord as well as in palp nerves and segmental nerves of the several first regenerated segments (Fig. 5G).

\section{Discussion}

Basing on our observations of $P$. elegans anterior and posterior regeneration, we divided the reparation process into 5 stages. Here we

Fig. 3. Regeneration of Pygospio elegans after the cut was performed between the $8^{\text {th }}$ and $9^{\text {th }}$ or the $10^{\text {th }}$ and $11^{\text {th }}$ body segments, which are the part of the thoracic region. A, B - 4 days anterior (A) and posterior (B) regenerates. The cut was performed between the $8^{\text {th }}$ and $9^{\text {th }}$ segments. C, D -7 days anterior $(C)$ and posterior (D) regenerates. The cut was performed between the $8^{\text {th }}$ and $9^{\text {th }}$ segments. At the anterior regeneration site, the head with missed 8 thoracic segments have been almost fully restored (C). E- G-14 dpa. E - two weeks after amputation the head and restored thoracic segments keep growing. F - parapodial anlagen with capillary chaetae and hooks are forming. G - at the "tail" site posterior segmentation and pygidium formation proceeds. The cut was performed between the $8^{\text {th }}$ and $9^{\text {th }}$ segments. $\mathrm{H}, \mathrm{I}$ - posterior regeneration 3 weeks after amputation. J, K - posterior regeneration 4 weeks after amputation. L, M - posterior regeneration 5 weeks after amputation, the cut was performed after the $10^{\text {th }}$ body segment. I, K, M Retaining hooded hooks on neuropodiae of newly formed $11^{\text {th }}$ and $12^{\text {th }}$ thoracic segments are clearly seen. White dashed line marks the cut line. Numbers indicate the corresponding thoracic segments.

Abbreviations: $A 1$ - the first abdominal segment. Scale bar: $100 \mu \mathrm{m}$.

Рис. 3. Регенерация Pygospio elegans после разреза между 8-м и 9-м или 10-м и 11-м сегментами тела, которые являются частью грудного отдела. А-B - четырехдневные передний (А) и задний (B) регенераты. Разрез выполнен между 8-м и 9-м сегментами. C-D - семидневные передний (C) и задний (D) регенераты. Разрез выполнен между 8-м и 9-м сегментами. Спереди практически полностью восстановлены головной отдел и 8 недостающих грудных сегментов (C). E-G - 14 дпа. $\mathrm{E}$ - через две недели после ампутации продолжается рост головного отдела и восстановленных грудных сегментов. F - формируются зачатки параподий с капиллярными и крючковидными щетинками. $\mathrm{G}$ - на хвостовом сайте регенерации формируется пигидий и продолжается процесс сегментации. Разрез был выполнен между 8-м и 9-м сегментами. $\mathrm{H}-\mathrm{M}$ - задняя регенерация. Н, I3 недели; J, K - 4 недели; L, M - 5 недель после ампутации. Разрез выполнен после 10-го сегмента тела. На I, K, М видно формирующиеся 11-й и 12-й грудные сегменты, на которых сохраняются крючковидные невроподиальные щетинки. Белый пунктир маркирует линию разреза. Числами указаны номера грудных сегментов.

$A 1$ - первый абдоминальный сегмент. Масштаб: $100 \mu \mathrm{m}$. 

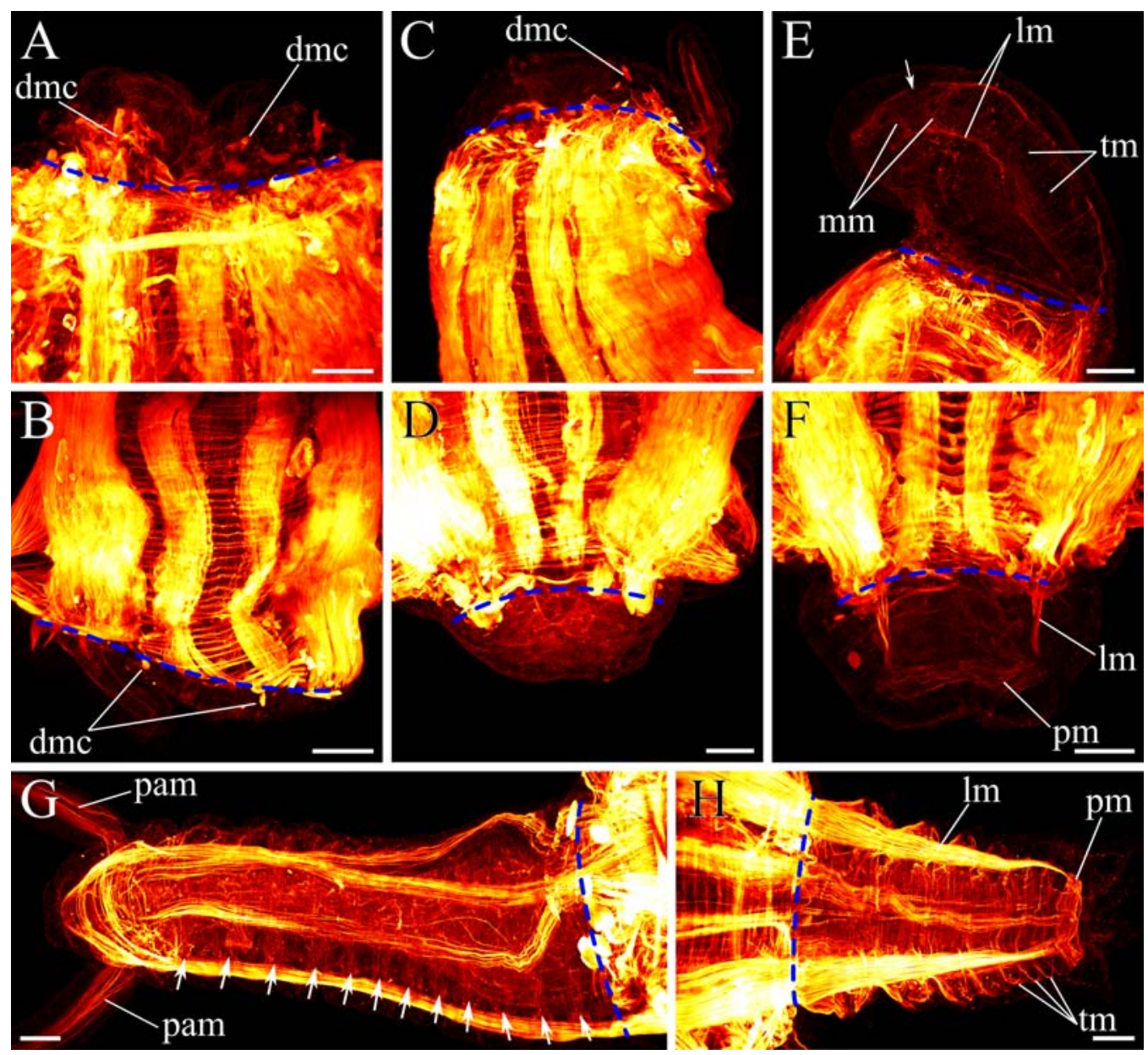

Fig. 4. TRITC-phalloidin labeling of Pygospio elegans regenerating musculature. A, C, E, G - the anterior part regeneration at $12 \mathrm{hpa}, 2 \mathrm{dpa}, 4 \mathrm{dpa}$ and $7 \mathrm{dpa}$, respectively. The head is to the top. B, D, F, H regeneration of "tail" part at $12 \mathrm{hpa}, 2 \mathrm{dpa}, 4 \mathrm{dpa}$ and $7 \mathrm{dpa}$, respectively. "Tail" part is to the bottom. Arrow in E labels the mouth opening. Blue dashed line marks the cut line.

Abbreviations: dmc — degrading muscle cells; $1 \mathrm{~m}$ — longitudinal muscles; mm — musculature of mouth opening; pm — pygidium muscles; pam — palp muscles; tm — transverse muscles. Scale bar: $50 \mu \mathrm{m}$.

Рис. 4. Регенерация мускулатуры Pygospio elegans. Окраска TRITC-конъюгированным фаллоидином. A, C, E, G - регенерация головной части на стадиях 12 чпа, 2 дпа, 4 дпа и 7 дпа, соответственно. Головной конец направлен вверх. B, D, F, H - регенерация заднего конца тела на стадиях 12 чпа, 2 дпа, 4 дпа и 7 дпа, соответственно. Задний конец направлен вниз. Синим пунктиром обозначена линия разреза.

Обозначения: dmc - деградирующие мускульные клетки; $1 \mathrm{~m}$ - продольные мышцы; mm - мышцы, окружающие ротовое отверстие; pam — мышцы пальп; pm — мышцы пигидия; tm — поперечные мышцы. Масштаб: $50 \mu \mathrm{m}$.

Рис. 5. Восстановление катехоламинергической системы в ходе регенерации головного конца тела. A - сразу после ампутации; B - 2 дпа; C - 3 дпа, вид со спины; D - 3 дпа, вид с вентральной стороны; E - 4 дпа, вид со спины; F - 4 дпа, вид с брюшной стороны; G - 7 дпа. Головной конец направлен вверх. Наконечники стрелок указывают на первые пояляющиеся нервные элементы. Белым пунктиром обозначена линия разреза.

Обозначения: cg — церебральный ганглий; dln - спинной продольный нерв; ра - нервы пальп; vnc вентральная нервная цепочка. Масштаб: $50 \mu \mathrm{m}$. 

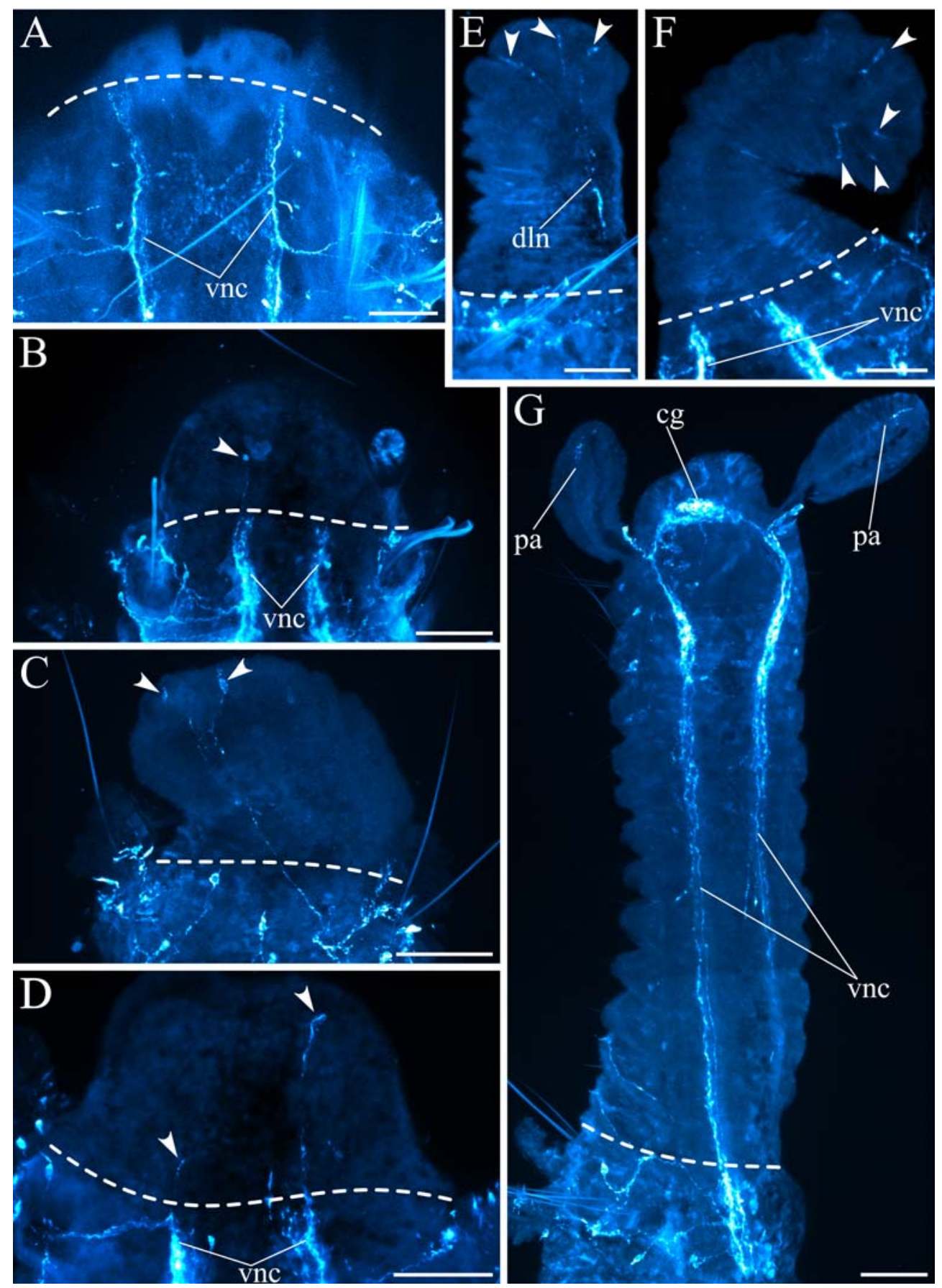

Fig. 5. The catecholaminergic system restoration during head regeneration. A — immediately after ablation; B - 2 dpa; C - 3 dpa, dorsal view; D - 3 dpa, ventral view; E - 4 dpa, dorsal view; F - 4 dpa, ventral view; $\mathrm{G}-7 \mathrm{dpa}$. Head is to the top. Arrowheads indicate the first neural CA-positive elements. White dashed line marks the cut line.

Abbreviations: $\mathrm{cg}$ - cerebral ganglion; dln — dorsal longitudinal nerve; pa — palp nerves; vnc — ventral nerve cord. Scale bar: $50 \mu \mathrm{m}$. 

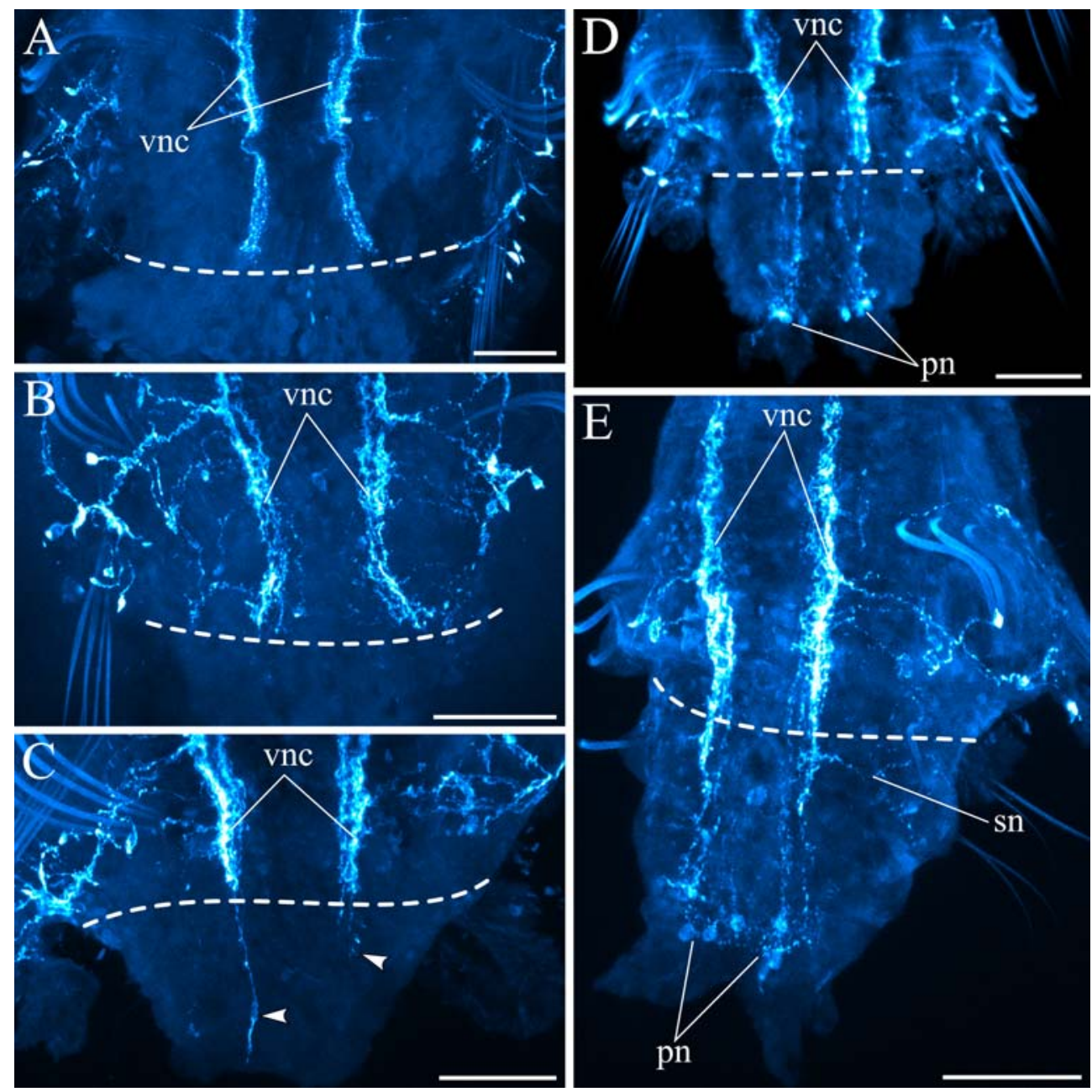

Fig. 6. The catecholaminergic system restoration during "tail" regeneration. A - immediately after ablation; B - 2 dpa; C - 3 dpa; D - 4 dpa; E - 7 dpa. "Tail" part is to the bottom. White dashed line marks the cut line.

Abbreviations: pn — nerve elements of the pygidium; sn — segmental nerves; vnc — ventral nerve cord. Arrowheads indicate the first neural CA-positive elements. Scale bar: $50 \mu \mathrm{m}$.

Рис. 6. Восстановление катехоламинергической системы в ходе регенерации «хвостового» конца тела. А - сразу после ампутации; В - 2 дпа; $\mathrm{C}-3$ дпа; D -4 дпа; E - 7 дпа. «Хвост» направлен вниз. Белым пунктиром обозначена линия разреза.

Обозначения: pn - нервные элементы пигидия; sn - нервы сегментов; vnc - вентральная нервная цепочка. Наконечники стрелок указывают на первые появляющиеся нервные элементы.

match the regeneration stages with time post amputation for the worms cut after the $20^{\text {th }}$ body segment that regenerate at $18{ }^{\circ} \mathrm{C}$.

The first stage of both anterior and posterior regeneration occurs during the 24 hpa and includes the minimizing of the wound surface by muscle contraction and covering the cut site with wound epithelium. During the second stage (1-2 dpa) anterior and posterior blastemae formation and growth proceed. Both blastemae become prominent by the end of the $2^{\text {nd }}$ day but no signs of organogenesis are visible. At this 
stage the signs of muscle destruction at the amputation site are detected which is in line with active blastema formation. In the regenerating nervous system, the first catecholamine-positive cells are visible. The third stage ( $3 \mathrm{dpa})$ displays the beginning of organogenesis (head and missing thoracic segments on the anterior site and pygidium on the posterior site). The anterior and posterior buds elongate, and the mouth and anus openings become distinguishable.

On the fourth stage of regeneration (4 dpa) the first external signs of segmentation can be observed. The regenerating anterior part contains the prostomium and thoracic part anlage with a few anterior segments already visible. On the posterior regeneration site pygidium with the rudiments of four cirri is forming, and simultaneously the segment formation from the newly formed growth zone initiates so that a few segments can be distinguished. This stage is marked by the intensive formation of longitudinal muscle bands and catecholamine-positive nerve elements in the posterior part, as well as the appearance of the first muscle fibers in the anterior regenerating part.

On the fifth stage ( $7 \mathrm{dpa}$ ) the external boundaries of all newly formed thoracic segments are detectable, the palp buds elongate, and the rudiments of nuchal organs appear. At the posterior site the segmentation becomes more prominent and the growth of pygidium proceeds. The main elements of musculature and catecholaminergic nervous system are fully formed in regenerating parts from both sides.

Thus, during 1 week, $P$. elegans restores the missing regions of the body after traumatic amputation by the formation of the small but fully formed regenerated parts. Several weeks further, they reach their full size and become almost indistinguishable from the old body parts (data not shown).

The regeneration of $P$. elegans after natural fragmentation or experimental amputation was previously described by several authors (Malikova, 1975; Malikova, Plyustch, 1980; Gibson, Harvey, 2000; Lindsay et al., 2007; Lindsay et al., 2008). Gibson \& Harvey (2000) observed the regeneration of $P$. elegans in response to asexual reproduction under laboratory conditions. After the fragmentation of the body into usually two or, less commonly, 3-6 pieces the regeneration of anterior and posterior parts started with the healing of the wound surface with the epidermis and blastema formation in both regenerative sites. Similar processes were observed by Malikova \& Plyustch (1980) and by Lindsay et al. (2007) during head reparation, though the speed of regeneration varied depending on the cultivation temperature. Thus, our observations of the early steps of $P$. elegans regeneration process are in line with those described in literature and resemble very much the course of regeneration described for other polychaetes (de Jong, Seaver, 2017; Kozin et al., 2017; Planques et al., 2019). The early events are similar for both anterior and posterior regeneration. The dynamics of cell proliferation should be monitored to detect whether the wound epithelium spreads without increase of cell number and the cell divisions start only with the beginning of blastema formation after $24 \mathrm{hpa}$ as it was demonstrated for P. dumerilii and C. teleta (de Jong, Seaver, 2017; Planques et al., 2019). Another important issue of annelid regeneration — the source of blastemal cells — will also be a subject of our future research.

According to our data, the number of chaetigers restored at once at the anterior side after the abdominal dissection was 12 , which corresponds to the number of thoracic segments in the most representatives of the studied population. Similar observations were reported by Gibson \& Harvey (2000) and Lindsay with coauthors (Lindsay et al., 2007) who described simultaneous regeneration of the exact number of amputated thoracic segments at the anterior side. Surprisingly, Malikova (1975) described the restoration of 11 anterior segments each time the dissection was performed at any level after the $12^{\text {th }}$ segment in worms possessing 12 thoracic segments. This is confusing since the experiments were carried out with the same population we are currently working on. This inconsistency may be explained by the confusion in segment counting as in another set of 
experiments the authors describe the $12^{\text {th }}$ segment as the first one bearing gills (Malikova, Plyustch, 1980).

It was noticed by Ivanov (Ivanov, 1912) that in case of anterior regeneration many polychaete worms restore the exactly defined number of segments which corresponds to the number of segments specific for their larvae. Indeed, Spirographis spallanzanii Viviani, 1805 (Sabellidae) regenerates head structures and three segments, which is the number of segments in the nectochaete larva and corresponds to the anterior part of the thoracic region of the juvenile and adult worm. During the anterior regeneration of the spionid worm Polydora hoplura Claparède, 1868 the mesodermal anlage in the forming bud divides into six somites and forms six segments. These first six segments lack reproductive glands and nephridia and are considered to be of larval origin. During the anterior regeneration of $P$. elegans dissected after the $20^{\text {th }}$ body chaetiger, we observed the formation of the head structures and 12 thoracic segments from the anterior blastema. The number of thoracic segments in $P$. elegans may vary from 10 to 13 chaetigers (Gibson, Harvey, 2000; Radashevsky et al., 2016), but for the examined population from the Barents Sea we mostly observed 12 thoracic segments. As described by different authors $P$. elegans larvae can reach 12-19 chaetigers before settling (Kesäniemi et al., 2012; Radashevsky et al., 2016). Korotkova described premetamorphic larvae of P. elegans from Barents Sea possessing 12 segments (Korotkova, 1997). Thus, the thoracic segments that we observed emerging simultaneously during anterior regeneration may correspond to the larval segments of $P$. elegans from the studied population, which is in line with Ivanov's data. However, the questions arise how many segments $P$. elegans with, for example, 10 thoracic segments would restore during anterior regeneration, and how the anterior regeneration would proceed in other spionids with different number of larval segments.

During the posterior regeneration, $P$. elegans forms the pygidium with cirri buds and the growth zone which starts to produce segments simultaneously with the pygidium formation so that a few segments can be already distinguished by Day 4 . Malikova \& Plyustch also described the sequential formation of new segments in front of the regenerative bud that later transforms into pygidium and the growth zone (Malikova, Plyustch, 1980). On the contrary, Gibson \& Harvey (2000) described simultaneous establishing of finite, though variable, number of chaetigers in posterior blastema. Nevertheless, SEM investigations cannot clarify this situation and careful histological and gene expression studies are highly required to elucidate the dynamics of segmentation during posterior regeneration.

The course and timing of posterior regeneration of $P$. elegans at $18{ }^{\circ} \mathrm{C}$ we observed coincide a lot with those described for $P$. dumerilii which is one of the most popular annelid model for studying developmental and evolutionary biology (Planques et al., 2019). This makes it very convenient to compare molecular mechanisms of regulation of reparation process in errant and sedentary annelids.

If the dissection is performed across the thoracic segments, $P$. elegans restores the exact number of missing anterior segments which is in line with the data from other authors (Lindsay et $a l ., 2007)$. This can be the reflection of the ability of Pygospio larva to regenerate both anterior and posterior body parts. The $12^{\text {th }}$ segment larvae dissected between $6^{\text {th }}$ and $7^{\text {th }}$ segments formed regenerative blastemae on both sites and restored head with missing segments and pygidium in 10 days (Malikova, 1975). The ability to restore the exact number of missing segments implicate the existence of molecular mechanisms for segment counting and establishment of body boundaries that will become the subject of our further research.

In case we dissect the thoracic region of $P$. elegans the part of the worm which bears prostomium and 10 thoracic segments first restores pygidium with a few "tail" segments. As the "tail" part becomes longer, the segments adjacent to the dissection site change their identity to thoracic and abdominal segments as we can judge by some morphological features they ac- 
quire. We observe the growth of branchiae starting from $13^{\text {th }}$ segment, which indicates that these segments turn into abdominal ones. The thoracic segments $11^{\text {th }}$ and $12^{\text {th }}$ that were formed from newly grown "tail" segments possess fully formed parapodia but retain hooded hooks in neuropodia, which is the case for abdominal and "tail" segments but not for thoracic ones. Thus, newly regenerated "tail" segments assume the identity of abdominal ones as it happens during normal postlarval growth. Nevertheless, we cannot be sure that "tail" segments can be changed with full identity into thoracic segments. The longer observations are needed to clarify this situation. The molecular mechanisms of $P$. elegans certain body parts patterning should be studied as these mechanisms may be important for establishing the strict boundaries between newly forming body regions during regeneration.

The regeneration dynamics of muscle and nervous system of $P$. elegans is in line, in general, with the dynamics described for other annelids (Müller et al., 2003; Müller, 2004; Lindsay et al., 2008; Weidhase et al., 2014; Kozin et al., 2017). The different timing of the restoration comparing to other spionids (Lindsay et al., 2008) may vary due to the differences in experimental temperature. First signs of muscular regeneration become visible only at 3-4 dpa. At the anterior end the first elements that become distinguishable, are longitudinal muscles as well as the musculature, surrounding the mouth opening that is in great accordance with data available on amphinomids and cirratulids (Weidhase et al., 2014, 2015, 2016). It is interesting to note that during larval development in annelids, the longitudinal muscles appear far prior to transversal or oblique ones (McDougall et al., 2006; Fisher et al., 2010), so we can assume some similarities in muscle formation programs between larval development and regeneration. At the posterior end, the muscular regeneration begins with pygidial musculature and longitudinal muscular bands, indicating the leading role of the pygidium in caudal regeneration.

The catecholaminergic (CA) nervous system regenerates slower than muscles. Despite the first CA elements were detected at $2 \mathrm{dpa}$, the process begins slowly and has apparently saltatory character. Comparison with the data available on the annelid central nervous system regeneration (Müller et al., 2003; Müller, 2004; Lindsay et al., 2008; Weidhase et al., 2014, 2015, 2016; Kozin et al., 2017) together with our preliminary unpublished data clearly suggests that CA-positive structures appear later than many other nerve elements. We can suppose that CA-positive neurons in the central nervous system may play higher associative functions. Nevertheless, peripheral bipolar CApositive cells at the anterior end become visible at the third day after ablation and their projections are connected with the whole body via the dorsal longitudinal nerve, that supports the idea of a widespread distribution of bipartite regenerating part innervation from both central and peripheral nervous systems (Kozin et al., 2017; Özpolat, Bely, 2016).

At the posterior end numerous CA-positive neurons in the pygidium as well as CA-positive fibers in ventral nerve cord appear by 4 dpa. After that the posterior regeneration is to increase the number of segments indistinguishable from the normal postlarval segment addition. Comparison with anterior regeneration reveals that anterior nervous system regeneration takes much more time than posterior, that can probably be explained by higher complexity of the anterior end and simultaneous restoration of not only the terminal region, but also several anterior segments.

\section{Conclusion and future perspectives}

To summarize, the sedentary spionid Pygospio elegans demonstrates high potencies in both anterior and posterior reparation process. Its tolerance to different environmental conditions, cosmopolitism, variable reproductive strategies and capability of being cultivated in the laboratory make $P$. elegans a convenient and perspective model to study not only regeneration processes and underlying molecular mechanisms but also molecular control of larval development, the cellular aspects of larval and postlar- 
val growth as well as genetic mechanisms of body patterning during ontogenesis. The morphological studies presented in this paper alongside with the staging of regeneration process are the promising scientific background for future molecular research.

\section{Acknowledgments}

We are thankful to Dr. M. Makarov for providing accommodation and facilities for field work at the Barents Sea. The research was performed at the Research park of Saint Petersburg State University "Center for molecular and cell technologies," "CHROMAS", "Culture Collection of Microorganisms", and "Observatory of Environmental Safety Center" of Saint Petersburg State University, and "Taxon" Research Resource Center of Zoological Institute RAS (http://www.ckp-rf.ru/ckp/3038/?sphra se_id $=88790$ 24). This research is supported by RFBR grant 18-04-00450 to ELN and the budget program AAAA-A19-119020690076-7 to VVS. We are also grateful to the three anonymous reviewers, whose useful comments helped us to significantly improve the manuscript.

\section{References}

Anger K., Anger V., Hagmeier E. 1986. Laboratory studies on larval growth of Polydora ligni, Polydora ciliata and Pygospio elegans (Polychaeta, Spionidae) // Helgoländer Meeresunters. Vol.40. P.277-395.

Anger V. 1984. Reproduction in Pygospio elegans (Spionidae) in relation to its geographical origin and to environmental conditions: a preliminary report // Fort. Zool. Vol.29. P.45-51.

Armitage D.L. 1979. The ecology and reproductive cycle of Pygospio elegans claparède (Polychaeta: Spionidae) from Tomales Bay, California. The faculty of the Graduate school University of the Pacific. Thesis. Stockton, California. $81 \mathrm{p}$.

Bakalenko N.I., Novikova E.L., Nesterenko A.Y., Kulakova M.A. 2013. Hox gene expression during postlarval development of the polychaete Alitta virens // Evodevo. Vol.4. No.1. P1-17.

Bely A.E. 2006. Distribution of segment regeneration ability in the Annelida // Integr. Comp. Biol. Vol.46. No.4. P.508-518.

Bely A.E., Zattara E.E., Sikes J.M. 2014. Regeneration in spiralians: evolutionary patterns and developmental processes // Int. J. Dev. Biol. Vol.58. P.623-634.

Berrill N.J. 1952. Regeneration and budding in worms // Biological Reviews. Vol.27. No.4. P.401-438. de Jong D.M., Seaver E.C. 2016. A Stable Thoracic Hox Code and Epimorphosis Characterize Posterior Regeneration in Capitella teleta // PLoS One. Vol.11. No.2. P.1-34.

de Jong D.M. Seaver E.C. 2017. Investigation into the cellular origins of posterior regeneration in the annelid Capitella teleta // Regeneration (Oxf). Vol.5. P.61-77.

Ferrier D.E. 2012. Evolutionary crossroads in developmental biology: annelids // Development. Vol.139. No.15. P.2643-2653.

Fischer A.H., Henrich T., Arendt D. 2010. The normal development of Platynereis dumerilii (Nereididae, Annelida) // Front. Zool. Vol.7. No.31. P.1-39.

Fauchald K., Jumars P.A. 1979. The diet of worms: a study of polychaete feeding guilds // Oceanogr. Mar. Biol. Ann. Rev. Vol.17. P.193-284.

GBIF Secretariat. 2019. Pygospio elegans Claparède, 1863 // GBIF Backbone Taxonomy. Checklist dataset https://doi.org/10.15468/39omei URL: https:// www.gbif.org/ru/species/2321271 accessed via GBIF. org on 2020-05-17.

Gibson G.D., Harvey J.M. 2000. Morphogenesis during asexual reproduction in Pygospio elegans Claparede (Annelida, Polychaeta) // Biol. Bull. Vol.199. No.1. P.41-49.

Gudmundsson H. 1985. Life history patterns of polychaete species of the family Spionidae // J. Mar. Biol. Assoc. UK. Vol.65. P.93-111.

Hannerz L. 1956. Larval development of the polychaete families Spionidae Sars, Disomidae Mesnil and Poecilochaetidae n. fam. in the Gullmar Fjord (Sweden) // Zool. Bidr. Upps. Vol.31. P.1-204.

Hempel C. 1957. Über den Röhrenbau und die Nahrungsauinahme einiger Spioniden (Polychaeta sedentaria) der deutschen Küsten // Helgoländer wiss. Meeresunters. Bd.6. S.100-135.

Hyman L. 1940. Aspects of regeneration in annelids // The American Naturalist. Vol.74. No.755. P.513-527.

Ivanov P.P. 1912. [Regenerative processes in polychaete worms and their relation to the ontogenesis and morphology of annelids]. Saint-Petersburg. 239 p. [In Russian]

Ivanov P.P. 1944. [Primary and secondary metamerism of the body] // Zhurnal obshchei biologii. Vol.5. No.2. P.61-95 [in Russian].

Kesäniemi J.E., Geuverink E., Knott K.E. 2012. Polymorphism in developmental mode and its effect on population genetic structure of a spionid polychaete, $P y$ gospio elegans // Integr. Comp. Biol. Vol.52. No.1. P.181-96.

Korotkova G.P. 1997. [Regeneration in animals]. SaintPetersburg: Izdatelstvo Sankt-Peterburgskogo Universiteta. 480 p. [In Russian]

Kostyuchenko R.P., Kozin V.V., Kupriashova E.E. 2016. Regeneration and asexual reproduction in annelids: cells, genes, and evolution // Biology Bulletin. Vol.43. No.3. P.231-241.

Kozin V.V., Filippova N.A., Kostyuchenko R.P. 2017. Regeneration of the nervous and muscular system 
after caudal amputation in the polychaete Alitta virens (Annelida: Nereididae) // Russian Journal of Developmental Biology. Vol.48. No.3. P.198-210.

Lindsay S.M., Jackson J.L., He S.Q. 2007. Anterior regeneration in the spionid polychaetes Dipolydora quadrilobata and Pygospio elegans // Mar. Biol. No.150. P.1161-1172.

Lindsay S.M., Jackson J.L., Forest D.L. 2008. Morphology of anterior regeneration in two spionid polychaete species: implications for feeding efficiency // Invertebrate Biology Vol.127. No.1. P.65-79.

Malikova I.G. 1975. [Regeneration in Pygospio elegans at different stages of ontogenesis] // Vestnik Leningradskogo Universiteta. Vol.9. P.35-40 [in Russian].

Malikova I.G., Plusch T.A. 1980. [Morphogenetic processes during the regeneration of the polychaete $P y$ gospio elegans from fragments of the body]. Ms. Deposited in VINITI. No.1250-80. 18 p. [In Russian]

Malikova I.G., Sokolova I.O. 1992à. [On the morphology of the growth zone of Pygospio elegans Claparède (Polychaeta, Spionidae)] // Mnogoshchetinkovye chervi i ikh ekologitcheskoe znachenie. Saint-Petersburg: ZIN RAN. P.39-43 [in Russian].

Malikova I.G., Sokolova I.O. 1992b. [Formation of metamerism in Pygospio elegans Claparède (Polychaeta: Spionidae)] // Mnogoshchetinkovye chervi i ikh ekologitcheskoe znachenie. Saint-Petersburg: ZIN RAN. P.43-47 [in Russian]

McCall P.A. 1977. Community patterns and adaptive strategies of the infaunal benthos of Long Island Sound // J. Mar. Res. Vol.35. No.2. P.221-266.

McDougall C., Chen W.C., Shimeld S. M., Ferrier D.E.K. 2006. The development of the larval nervous system, musculature and ciliary bands of Pomatoceros lamarckii (Annelida): heterochrony in polychaetes // Front. Zool. Vol.3. No.16. P.1-14.

Morgan T.S. 1997. The formation and dynamics of Pygospio elegans tube-beds in the Somme Bay, France. $\mathrm{PhD}$ thesis. Southampton: University of Southampton. 423 p.

Morgan T.S., Rogers A.D., Paterson G.L.J., Hawkins L.E., Sheader M. 1999. Evidence for poecilogony in Pygospio elegans (Polychaeta: Spionidae) // Mar. Ecol. Prog. Ser. Vol.178. P.121-132.

Müller M.C.M., Berenzen A., Westheide W. 2003. Experiments on anterior regeneration in Eurythoe complanata ("Polychaeta", Amphinomidae): reconfiguration of the nervous system and its function for regeneration // Zoomorphology. Vol.122. P.95-103.

Müller M.C.M., 2004. Nerve development, growth and differentiation during regeneration in Enchytraeus fragmentosus and Stylaria lacustris (Oligochaeta) // Dev. Growth. Differ. Vol.5. P. 471-478.

Novikova E.L., Bakalenko N.I., Nesterenko A.Y., Kulakova M.A. 2013. Expression of Hox genes during regeneration of nereid polychaete Alitta (Nereis) virens (Annelida, Lophotrochozoa) // Evodevo. Vol.4. No.1. P.1-16.

Özpolat B.D., Bely A.E. 2016. Developmental and molecular biology of annelid regeneration: a comparative review of recent studies // Curr. Opin. Genet. Dev. Vol.40. P.144-153.

Planques A., Malem J., Parapar J., Vervoort M., Gazave E. 2019. Morphological, cellular and molecular characterization of posterior regeneration in the marine annelid Platynereis dumerilii // Dev. Biol. Vol.445. No.2. P.189-210.

Radashevsky V.I., Pankova V.V., Neretina T.V., Stupnikova A.N., Tzetlin A.B. 2016. Molecular analysis of the Pygospio elegans group of species (Annelida: Spionidae) // Zootaxa. Vol.4083. No.2. P.239-250.

Rasmussen E. 1953. Asexual reproduction in Pygospio elegans Claparède (Polychaeta sedentaria) // Nature. Vol.171. No.4365. P.1161-1162.

Rasmussen E., 1973. Systematics and ecology of the Isefjord marine fauna (Denmark) // Ophelia. Vol.11. P.1-495.

Schlotzer-Schrehardt U. 1991. Ultrastructural differentiation of nuchal and dorsal organs during postembryonic and sexual development of Pygospio elegans Claparede (Polychaeta: Spionidae)//Ophelia Suppl. Vol.5 P.633-640.

Smidt E.L.B. 1951. Biological studies of the invertebrate fauna of the Harbour of Copenhagen // Vidensk. Medd. Dans. naturhist. Foren. København Vol.107. P.235-316.

Söderström A. 1920. Studien über die Polychätenfamilie Spionidae. Inaugural Dissertation. Uppsala: Almquist \& Wicksells. $288 \mathrm{~S}$.

Struck T.H., Paul C., Hill N., Hartmann S., Hösel C., Kube M., Lieb B., Meyer A., Tiedemann R., Purschke G., Bleidorn C. 2011. Phylogenomic analyses unravel annelid evolution // Nature. Vol.471. No.7336. P.95-98.

Szabó R., Ferrier D.E. 2014. The dynamics of alkaline phosphatase activity during operculum regeneration in the polychaete Pomatoceros lamarckii // Int. J. Dev. Biol. Vol.58. No.6-8. P.635-42.

Thonig A. 2018. The effect of variation in development mode on the population dynamics of a spionid polychaete (Pygospio elegans) in a heterogeneous environment. Dissertation. Jyväskylä: University of Jyväskylä. 199 p.

Thonig A., Knott E., Kesäniemi J.E., Hansen B.W, Banta G.T. 2016. Population and reproductive dynamics of the polychaete Pygospio elegans in a boreal estuary complex// Invertebrate Biology Vol.135. No.4. P.370384.

Weidhase M., Bleidorn C., Helm C. 2014. Structure and anterior regeneration of musculature and nervous system in Cirratulus cf. cirratus (Cirratulidae, Annelida) // J. Morphol. Vol.275. P.1418-1430.

Weidhase M., Helm C., Bleidorn C. 2015. Morphological investigations of posttraumatic regeneration in Timarete cf. punctata (Annelida: Cirratulidae) // Zool. Lett. Vol1. No.20. P. 1-16.

Weidhase M., Bleidorn C., Beckers P., Helm C. 2016 Myoanatomy and anterior muscle regeneration of the fireworm Eurythoe cf. complanata (Annelida: Amphinomidae) // J. Morphol. Vol. 277. No.3. P.306315 . 
Weigert A., Helm C., Meyer M., Nickel B., Arendt D., Hausdorf B., Santos S.R., Halanych K.M., Purschke G., Bleidorn C., Struck T.H. 2014. Illuminating the base of the annelid tree using transcriptomics // Mol. Biol. Evol. Vol.31. No.6. P.1391-401.
Wells G.P. 1952. The respiratory significance of the crown in the polychaete worms Sabella and Myxicola // Proc. R. Soc. Lond. B Biol. Sci. Vol.140. No.898. P.70-82.

Responsible editor E.N. Temereva 